\title{
Adaptation and validation of content of the sedentary behavior questionnaire
}

\author{
Consuelo Vélez Álvarez* \\ José Armando Vidarte Claros** \\ Alejandro Arango Arenas *** \\ Brayan Esneider Patiño Palma**** \\ Yudhy Alexandra Rondón Villamil *****
}

Received May 6, 2020 Accepted October 21, 2020

\begin{abstract}
Citar este artículo así:
Vélez Álvarez C, Vidarte Claros JA, Arango Arenas A, Patiño Palma BS, Rondón Villamil YA. Adaptation and validation of content of the sedentary behavior questionnaire. 2020 Hacia. Promoc. Salud. 2021; 26 (1): 141-155. https://doi.org/10.17151/hpsal.2021.26.1.12
\end{abstract}

\begin{abstract}
Objective: to validate and adapt the Sedentary Behavior Questionnaire. Materials and methods: content adaptation and validation study, the Delphi technique was used, 18 experts evaluated the items of the questionnaire on a Likert scale regarding their relevance, utility, clarity, written form and length. Results: the questionnaire through its items assesses sedentary activity, the qualitative evaluation showed the need to adapt some questions regarding semantic to the Colombian context, the only item with an alpha lower than 0.70 was 7 , the item with the highest Cronbach alpha was 10 , the general Cronbach alpha of the instrument was 0.963 , which is considered to be of optimal reliability. Conclusions: The content validation process showed that the Sedentary Behavior Questionnaire is a valid instrument in its content that is easy to apply and fill out, it allows a first approach to the sedentary behaviors of the subjects that can be complemented with physical tests to define the level of sedentary lifestyle, the foregoing enables the structuring of promotion and prevention programs by applying an instrument adapted and validated to the Colombian context.

\section{Key words}

Physical activity, sedentarism, validation studies, psychometric tests, public health (source: $M E S H, N C I$ ).
\end{abstract}

\footnotetext{
*Doctor of Public Health, Universidad Autónoma de Manizales, Colombia. cva@autonoma.edu.co. Corresponding author. (D) orcid.org/0000-0001-7274-7304. Google

** PhD in Physical Activity and Sport Sciences, Universidad Autónoma de Manizales, Colombia. jovida@autonoma.edu.co (D) orcid.org/0000-0002-7982-3848. Google

${ }^{* * *}$ Master in Physical Activity and Sport. Universidad Autónoma de Manizales, Colombia. alejandro.arangoa@autonoma.edu.co (D) orcid.org/0000-0002-4476-0867. Google

**** Master in Physical Activity Sport, Universidad de Boyacá, Colombia. bpatino@uniboyaca.edu.co

(D) orcid.org/0000-0002-6932-0980. Google

Manual Therapy Specialist, Universidad de Boyacá, Colombia. yarondon@uniboyaca.edu.co

(D) orcid.org/0000-0002-8255-4562. Google
} 


\title{
Adaptación Y validación de contenido del Sedentary behavior questionnaire
}

\begin{abstract}
Resumen
Objetivo: adaptar y realizar la validación de contenido del Sedentary Behaviour Questionnaire. Materiales y métodos: estudio de adaptación y validación de contenido, se utilizó la técnica Delphi, participaron 18 expertos quienes evaluaron los ítems del cuestionario en una escala likert en cuanto a su pertinencia, relevancia, utilidad, claridad, redacción y extensión Resultados: El cuestionario a través de sus ítems evalúa la conducta sedentaria, la evaluación cualitativa mostró aspectos semánticos a tener en cuenta en algunas preguntas para realizar la adaptación al contexto colombiano, el único ítem con un alfa menor a 0,70 fue el 7, el ítem con mayor alfa de cronbach fue el 10, el alfa de cronbach general del instrumento fue de 0,963 este valor es considerado como de óptimo valor de confiabilidad; la versión definitiva incluye 3 nuevos ítems que complementan la valoración de la variable de interés. Conclusiones: el proceso de validación de contenido evidenció que el Sedentary Behaviour Questionnaire, es un instrumento válido en su contenido de fácil aplicación y diligenciamiento, permite una primera aproximación a las conductas sedentarias de los sujetos, este puede ser complementado con pruebas físicas para definir el nivel de sedentarismo, lo anterior posibilita la estructuración de programas de promoción y prevención, al aplicar un instrumento adaptado y validado al contexto colombiano.
\end{abstract}

\section{Palobras claves}

Actividad física, Sedentarismo, estudios de validación, pruebas psicométricas, salud pública (fuente:

DeCS, BIREME)

\section{Adaptação e validação de conteúdo do Sedentary behavior questionnaire}

\section{Resumo}

Objetivo: validar e adaptar o Sedentary Behavior Questionnaire. Materiais e métodos: estudo de adaptação e validação de conteúdo, foi utilizada a técnica Delphi, 18 especialistas avaliaram os itens do questionário em uma escala Likert quanto à relevância, utilidade, clareza, forma escrita e extensão. Resultados: o questionário por meio de seus itens avalia a atividade sedentária, a avaliação qualitativa mostrou a necessidade de adequação de algumas questões semânticas ao contexto colombiano, o único item com alfa inferior a 0,70 foi 7, o item com maior alfa de Cronbach foi 10, o alfa de Cronbach geral do instrumento foi de 0,963, considerado de confiabilidade ótima. Conclusões: O processo de validação de conteúdo mostrou que o Sedentary Behavior Questionnaire é um instrumento válido em seu conteúdo, de fácil aplicação e preenchimento, pois permite uma primeira abordagem dos comportamentos sedentários dos sujeitos que podem ser complementados com testes físicos para definir os nível de sedentarismo, o anterior permite a estruturação de programas de promoção e prevenção por meio da aplicação de um instrumento adaptado e validado para o contexto colombiano.

\section{Palavras Chave}

Atividade física, sedentarismo, estudos de validação, testes psicométricos, saúde pública (fonte: DeCS, BIREME) 


\section{Introduction}

The body movements that are produced by muscular action are defined as physical activity, which leads to energy consumption, a broad and encompassing concept that becomes a protective factor to prevent pathologies generated by inappropriate habits and lifestyles, such as the consumption of psychoactive substances, stress, environmental pollution, unbalanced diets, and sedentary behaviors, among others (1). The study of this last behavior is particularly relevant since physical inactivity, which leads to sedentary lifestyle, has been identified as a factor that contribute significantly to the cause of diseases such as diabetes, cardiovascular disease, osteoporosis and dyslipidemia, among others (2). Sedentary lifestyle includes activities such as sitting, watching television, and driving, among others, and has been defined based on activities associated with an energy expenditure $<1.5$ METs $(\mathrm{MET}=$ basal metabolic equivalent; $1 \mathrm{MET}=\sim$ $3.5 \mathrm{mlO} 2 / \mathrm{kg} / \mathrm{min})(3)$.

Sedentarism is now part of the daily lifestyles of children, young people and adults, mainly because people are increasingly staying at their desktops or with their technological equipment (2). According to the $\mathrm{WHO}$, at least $60 \%$ of the world's population is sedentary, with adults and the elderly being the most affected (4). The poor practice of physical activity and physical exercise, with low intensity and frequency, make sedentary lifestyle a public health problem (5). In Colombia, by 2018, 43.1\% of people between 18 to 64 years old did not comply with physical activity recommendations (6). The foregoing supports the emerging need for health and physical activity and sport professionals to generate new knowledge about sedentary behaviors and how they are expressed in populations in their lifetime.

Sedentary behavior is one that requires very little energy expenditure, it is also defined as the time in which people remain sitting, lying down or at rest, it is directly related to physical inactivity and with the greater probability of suffering chronic not transferable diseases as mentioned above (7).

One of the tools that has been used to support the analysis of sedentary behaviors is the Sedentary Behavior Questionnaire (SQB) designed in the United States in 2010 (8), in order to assess the amount of time spent on 9 behaviors (watching television, playing computer games, listening to music, talking on the phone, doing office work, reading, playing an instrument, doing arts or crafts, driving a car, bus or train), items that are evaluated separately for the days of the week and the weekend (9).

The SBQ has proven validity and reliability in countries like the United States $(8,10)$, Singapore (11), Turkey (12) and Spain (13).

Although the instrument has been validated in Spain, in its Spanish version there are terms that, in the opinion of the researchers, require revision and adaptation for the Colombian context where it has not been validated. This process allows making objective and accurate critical judgments about whether what is actually measured is valid - it measures what it should measure - and if it is really supported by empirical evidence. It also allows having an instrument adapted to the geographical and cultural reality, which finally translates into results with a lower margin of application error in future research. (14-16).

Therefore, this work aims to adapt and validate the content of the SBQ Spanish version in order to have an instrument that evaluates sedentary behaviors in the Colombian population.

\section{Materials and methods}

\section{Participants}

Following the procedural indications to achieve a reliable content validation product by Delphi technique, two groups were defined: the 
research group made up of professors from the Physiotherapy program of the University of Boyacá and by professors from the Human movement and health departments of the Autonoma University of Manizales. They consolidated and analyzed the results of the work developed by the experts who met the inclusion criteria to issue adequate concepts that would contribute to the achievement of the objective, since they were professionals with updated knowledge and experience in the subject of interest.

Twenty-six potential experts were selected, they should have the following characteristics

- Academic training: doctor or master's degree.

- Training and / or academic experience in the area of physical activity and sport or related areas.

- Experience in the area for at least 5 years as a teacher or researcher.

They were sent the informed consent, assessment tool and format via email. Finally, 18 experts responded.

\section{Questionnaire}

The SBQ was initially designed to assess the amount of time spent on 9 behaviors, which are: watching television, playing computer games, listening to music, talking on the phone, doing office work, reading, playing an instrument, doing arts and crafts, driving a car, bus or train. These activities were discriminated by day of the week and weekend, and given the questionnaire ease of application, it has been used in different populations with different health conditions and life cycles $(8,11-13,17)$.

We started from the Spanish version, it had been objectively translated following the cross-cultural adaptation guidelines, in the Spanish version 2 questions had been added to the questionnaire, after determining that the reliability and general interclass correlation of the SBQ questionnaire were excellent with an interval between 0.83 0.86 and in relation to the questions. Those indices ranged from moderate to excellent in 10 of the 11 sedentary behaviors ( 0.52 to 0.96$)(13)$.

For the present research and taking into account the above-mentioned factors, the instrument was retaken in the version validated in Spain that has 11 items and can be self-completed or applied by a researcher. However, it is necessary to adapt and validate its content to In the Colombian context, it should be clarified that according to the original instrument, the same questions are asked in two contexts like this: Monday through Friday, on a typical weekday, from the moment he gets up until he goes to bed (at night). On the weekend, on a typical weekend day, from waking up to going to bed (at night)

\section{Process}

The procedure was defined taking Blasco et al (18) and Bravo et al (19) as a reference. They propose three fundamental phases (preliminary, exploratory and final) for the development of the Delphi technique (Figure 1). 


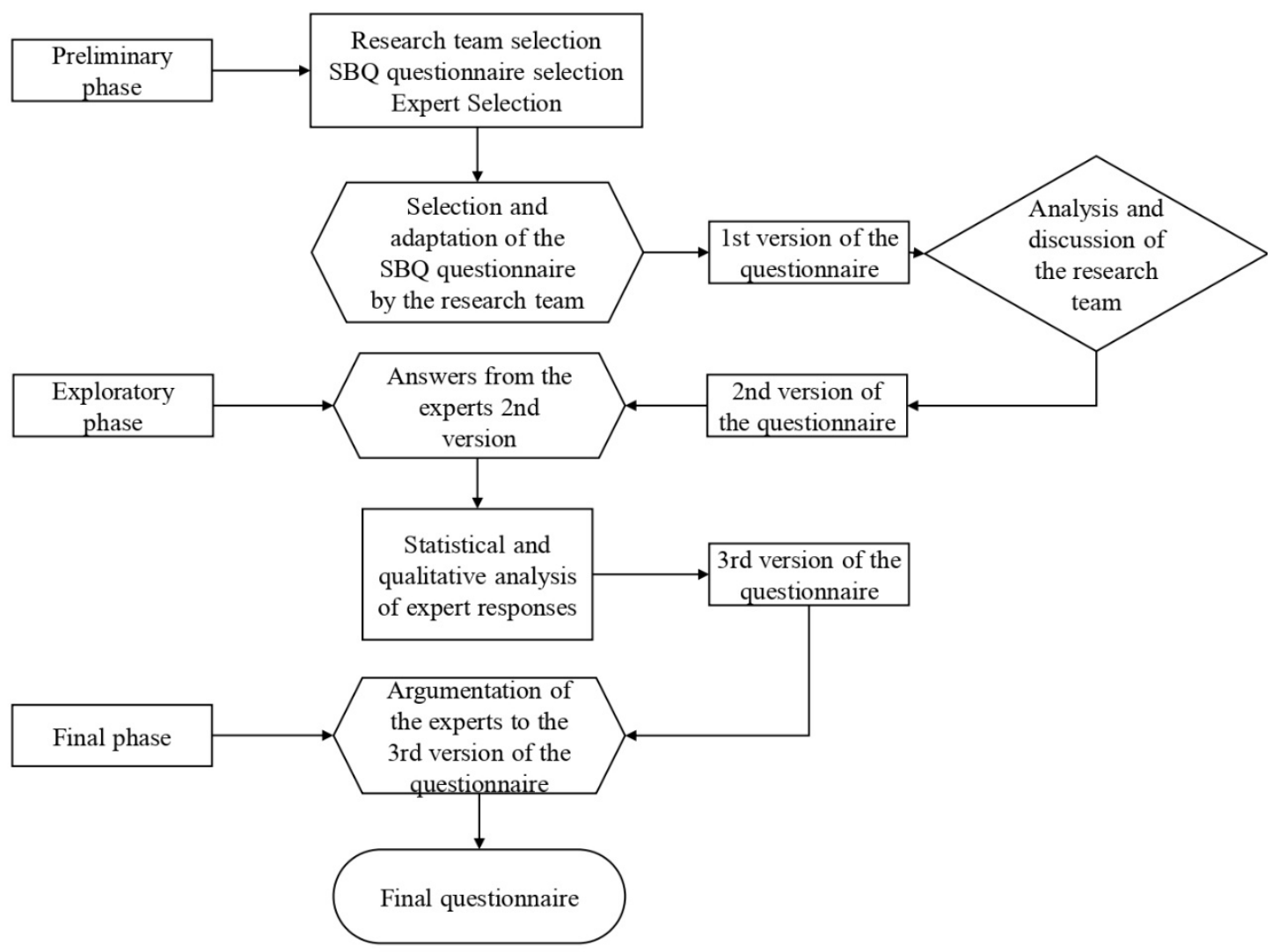

Figure 1. Delphi technical development stages Taken and adapted from Betancurth et al. (20).

\section{Preliminary phase:}

The instrument was selected, the research team and the group of experts were consolidated. To select the questionnaire, a search was carried out in different databases and repositories of instruments whose inclusion criterion was that they would evaluate the different sedentary behaviors and take into account the new dispositions and terminologies of sedentary lifestyle. The keywords used for the search were: sedentary behavior, surveys and questionnaires, physical activity, motor activity, Boolean connectors such as "and", "or" were used.

The questionnaire, research group and expert group were identified; for the selection of the questionnaire, a search of different bibliographic sites was done and developed on instruments that assess the different sedentary behaviors and that take into account the new provisions and terminologies of sedentarism.

The searches were carried out in Google Schoolar, Scielo, Medline, Ovid, ScienceDirect, which allowed to identify research works that studied habits and lifestyles such as physical activity, sports, and nutrition, among others, in which different instruments had been used. The IPAQ (International Physical Activity Questionnaire) stands out, it has been evaluated, used and recommended by the European Physical Activity Surveillance System (EUPASS) (21) and the SF- 
36 that aims to know the quality of life related to health in the participating subjects, being this reliable for the Colombian population (22-24).

With the analysis of these findings, it was possible to identify that in Colombia there is no validated questionnaire that evaluates sedentary behaviors, an aspect considered a problem in current generations especially due to behaviors such as increased time in front of screens and low levels of physical activity, which results in a lower energy expenditure than recommended, that is, 1.5 MET equivalents (22-24).

This led the research team to discuss and make changes to the initial version of the SBQ based on the bibliographic review in order to have the second version of the instrument that would be subject to evaluation by experts.

\section{Exploratory phase:}

The first version of the questionnaire, as previously mentioned, had some changes and a second version in a better format was consolidated. Then, it was sent to the experts who agreed to participate in the study via email and they were given a maximum response time of 15 days, anonymity was always preserved; The experts made the necessary recommendations in a pre-established template that evaluated the criteria of relevance, usefulness, clarity, written form and extension in each item, making reference to facial validity, each of the items and the criteria was evaluated in a Likert scale like this:

$\mathbf{1}=$ Does not meet the criteria

$\mathbf{2}=$ Low level of compliance

$3=$ Moderate level of compliance

$4=$ High level of compliance
Upon obtaining the evaluation of the group of experts, the research team tabulated and analyzed it in the SPSS V.24 program licensed by the Autonoma University of Manizales for its quantitative component. The recommendations given from the qualitative point of view and the adjustments suggested by the researchers to improve the understanding and quality of the questionnaire were made. The internal consistency of the questionnaire was evaluated through Cronbach's alpha by considering the reference points reported by Landis and Koch (25). A third version was obtained in this way.

\section{Final phase:}

This third version was discussed in the research group and, based on this last assessment, the final version of the questionnaire was structured. It consists of 14 items that can be used in the different research processes aimed at assessing sedentary behaviors in the Colombian population.

\section{Results}

\section{Preliminary phase}

The theoretical review carried out suggested some form adjustments that were made to the version adapted to Spanish. The research group selected the participants from the analysis of the criteria defined in the methodology; thus, experts from the discipline with more than 5 years of experience in academic, practical and research work in the area of Physical Activity and Sport participated. The 18 experts worked in different academic institutions, the level of training was Master's degree (55.6\%) and / or doctoral studies (44.4\%), the years of experience ranged between 7 and 37 with an average of 18.05 years $+/-8.9$ years (Table 1 ). 
Table 1. Characterization of the experts

\begin{tabular}{|c|c|c|c|c|}
\hline No & Job & Training Level & Area or discipline & $\begin{array}{c}\text { Years of } \\
\text { experience }\end{array}$ \\
\hline 1 & $\begin{array}{l}\text { Professor and researcher in } \\
\text { Physical Activity and Sports } \\
\text { Physiology. University of } \\
\text { Antioquia }\end{array}$ & $\begin{array}{l}\text { Pos-Doc, Ph.D. in } \\
\text { Physical Activity and } \\
\text { Health Sciences }\end{array}$ & $\begin{array}{l}\text { Physical Activity and } \\
\text { Health }\end{array}$ & 17 \\
\hline 2 & $\begin{array}{l}\text { Professor and researcher } \\
\text { in Sports Medicine, } \\
\text { Exercise Physiology, Sports } \\
\text { Biomechanics. University of } \\
\text { Caldas }\end{array}$ & $\mathrm{PhD}$ in Biology & Sports Medicine & 33 \\
\hline 3 & $\begin{array}{l}\text { Professor and researcher in } \\
\text { Sports Training, Physical } \\
\text { Preparation. University of } \\
\text { Pamplona }\end{array}$ & $\begin{array}{l}\text { Doctor of Physical } \\
\text { Culture }\end{array}$ & $\begin{array}{l}\text { Sports Training, } \\
\text { Football }\end{array}$ & 20 \\
\hline 4 & $\begin{array}{l}\text { Professor and Researcher in } \\
\text { Physical Activity and Health, } \\
\text { emphasis on Sedentarism and } \\
\text { Cognition Pontifical Catholic } \\
\text { University of Valparaiso }\end{array}$ & $\begin{array}{l}\text { Doctor of Physical } \\
\text { Activity and Sport } \\
\text { Sciences }\end{array}$ & $\begin{array}{l}\text { Physical Activity and } \\
\text { Health, emphasis } \\
\text { on Sedentarism and } \\
\text { Cognition }\end{array}$ & 15 \\
\hline 5 & $\begin{array}{l}\text { Research professor in Physical } \\
\text { Education and Physical Therapy. } \\
\text { University of Quindio }\end{array}$ & $\begin{array}{l}\text { Master in integral } \\
\text { intervention in the } \\
\text { sportsman }\end{array}$ & $\begin{array}{l}\text { Physical Education, } \\
\text { Physiotherapeutic } \\
\text { Intervention }\end{array}$ & 17 \\
\hline 6 & $\begin{array}{l}\text { Professor and researcher in } \\
\text { Sports Training and Physical } \\
\text { Activity. University of Caldas }\end{array}$ & $\begin{array}{l}\text { Doctor of Motor } \\
\text { Science }\end{array}$ & $\begin{array}{l}\text { Sports and Motor } \\
\text { Training }\end{array}$ & 25 \\
\hline 7 & $\begin{array}{l}\text { Research professor in Sports } \\
\text { Training. Santo Thomas } \\
\text { University }\end{array}$ & $\begin{array}{l}\text { Master's Degree in } \\
\text { Sports Training }\end{array}$ & Sports training & 10 \\
\hline 8 & $\begin{array}{l}\text { Research professor in Physical } \\
\text { Therapy. La Sabana University }\end{array}$ & $\begin{array}{l}\text { Master in integral } \\
\text { intervention in the } \\
\text { sportsman }\end{array}$ & $\begin{array}{l}\text { Physical Activity and } \\
\text { Physiotherapy }\end{array}$ & 10 \\
\hline 9 & $\begin{array}{l}\text { Research professor in Sports } \\
\text { Nutrition, Teaching and } \\
\text { Training. Central University of } \\
\text { Valle del Cauca } \\
\end{array}$ & $\begin{array}{l}\text { Master in integral } \\
\text { intervention in the } \\
\text { sportsman }\end{array}$ & $\begin{array}{l}\text { Sports Nutrition, Sports } \\
\text { Training, Physical } \\
\text { Activity }\end{array}$ & 10 \\
\hline 10 & $\begin{array}{l}\text { Research professor in Olympic } \\
\text { Gymnastics and Physical } \\
\text { Education. South Colombian } \\
\text { University. }\end{array}$ & $\begin{array}{l}\text { Master in integral } \\
\text { intervention in the } \\
\text { sportsman }\end{array}$ & $\begin{array}{l}\text { Physical Activity, } \\
\text { Physical Education }\end{array}$ & 37 \\
\hline 11 & $\begin{array}{l}\text { Research professor in Exercise } \\
\text { Physiology. University of } \\
\text { Cordoba }\end{array}$ & $\begin{array}{l}\text { PhD in Sports } \\
\text { Education and Sports } \\
\text { Science }\end{array}$ & $\begin{array}{l}\text { Physical Activity, } \\
\text { Health and Physical } \\
\text { Education }\end{array}$ & 25 \\
\hline
\end{tabular}




\begin{tabular}{|c|c|c|c|c|}
\hline No & Job & Training Level & Area or discipline & $\begin{array}{c}\begin{array}{c}\text { Years of } \\
\text { experience }\end{array}\end{array}$ \\
\hline 12 & $\begin{array}{l}\text { Research professor in Sports } \\
\text { Rehabilitation and Physical } \\
\text { Activity. University Santiago de } \\
\text { Cali }\end{array}$ & $\begin{array}{l}\text { Master in integral } \\
\text { intervention in the } \\
\text { sportsman }\end{array}$ & $\begin{array}{l}\text { Sports, Sports } \\
\text { Rehabilitation, } \\
\text { Epidemiology }\end{array}$ & 8 \\
\hline 13 & $\begin{array}{l}\text { Professor and researcher in } \\
\text { Biomechanics and Physical } \\
\text { Activity. Free University of } \\
\text { Bogotá }\end{array}$ & $\begin{array}{l}\text { Master in integral } \\
\text { intervention in the } \\
\text { sportsman }\end{array}$ & $\begin{array}{l}\text { Applied Sciences } \\
\text { (biomechanics) and } \\
\text { Physical Exercise for } \\
\text { Health }\end{array}$ & 22 \\
\hline 14 & $\begin{array}{l}\text { Teacher-researcher in Physical } \\
\text { Education and Sport. Juan } \\
\text { de Castellanos University } \\
\text { Foundation }\end{array}$ & $\begin{array}{l}\text { Master in Pedagogy of } \\
\text { Physical Culture }\end{array}$ & $\begin{array}{l}\text { Physical Education and } \\
\text { Sport }\end{array}$ & 8 \\
\hline 15 & $\begin{array}{l}\text { Professor-researcher in Sports } \\
\text { Training, Exercise Physiology. } \\
\text { Central Valle University }\end{array}$ & $\begin{array}{l}\text { Master's Degree in } \\
\text { Exercise Physiology }\end{array}$ & $\begin{array}{l}\text { Didactics of Physical } \\
\text { Education, Physical } \\
\text { Conditioning, Exercise } \\
\text { Prescription, Healthy } \\
\text { Sedentary Populations } \\
\text { and Competition Sports }\end{array}$ & 21 \\
\hline 16 & $\begin{array}{l}\text { Professor-Researcher in Sports } \\
\text { Training and Physical Activity } \\
\text { University of Cuenca }\end{array}$ & $\begin{array}{l}\mathrm{PhD} \text { in Applied } \\
\text { Biosciences }\end{array}$ & $\begin{array}{l}\text { Sports Training, } \\
\text { Physiology and } \\
\text { Physical Activity }\end{array}$ & 12 \\
\hline 17 & $\begin{array}{l}\text { Professor-researcher in Sports } \\
\text { Physiotherapy, Exercise } \\
\text { Prescription. University of } \\
\text { Cauca }\end{array}$ & $\begin{array}{l}\text { Master in integral } \\
\text { intervention in the } \\
\text { sportsman }\end{array}$ & $\begin{array}{l}\text { Sports Physiotherapy, } \\
\text { Physical Activity, } \\
\text { Exercise Prescription, } \\
\text { Noncommunicable } \\
\text { Diseases }\end{array}$ & 7 \\
\hline 18 & $\begin{array}{l}\text { Professor-researcher in Sports } \\
\text { Medicine and Physical Activity. } \\
\text { Universidad Mayor de Santiago } \\
\text { de Chile }\end{array}$ & Doctor of Nutrition & $\begin{array}{l}\text { Sports Medicine, } \\
\text { Exercise Physiology, } \\
\text { Physical Activity and } \\
\text { Sedentarism }\end{array}$ & 28 \\
\hline
\end{tabular}

Source: Own elaboration

\section{Exploratory phase}

The pertinent adjustments related to the Colombian context were made to the second version of the questionnaire developed by the research team.
Table 2 presents the qualitative results for each item derived from the evaluation by the experts. It is possible to observe that some recommended to change wording and even word formulation in order for the question to be understood and adapted to the Colombian context. 
Table 2. Qualitative results for each item

\begin{tabular}{|c|c|}
\hline Original version item & Qualitative observations \\
\hline $\begin{array}{l}1 \text { How much time do you spend watching } \\
\text { TV? }\end{array}$ & $\begin{array}{l}\text { Easy to understand; very important item since it is the time dedicated to } \\
\text { sedentarism and the amount of self-reporting; change the word "employ" for } \\
\text { "pass". }\end{array}$ \\
\hline $\begin{array}{l}2 \text { How much time do you spend sitting } \\
\text { down? }\end{array}$ & $\begin{array}{l}\text { It is important to ask "eating without displacement" would be better; it is } \\
\text { clear; change employment for passing. }\end{array}$ \\
\hline $\begin{array}{l}3 \text { How much time do you spend lying } \\
\text { down? }\end{array}$ & $\begin{array}{l}\text { The word lying down does not apply to our environment; it is suggested lying } \\
\text { down }\end{array}$ \\
\hline $\begin{array}{l}4 \text { How much time do you spend playing } \\
\text { computer or video games sitting down? }\end{array}$ & $\begin{array}{l}\text { Change employment for passing; change the term computer, as it is not } \\
\text { common in our context, it should be changed to any technological equipment; } \\
\text { relevant question. }\end{array}$ \\
\hline $\begin{array}{l}5 \text { How much time do you spend listening } \\
\text { to music sitting down? }\end{array}$ & It is a clear and pertinent question since many people do it today. \\
\hline $\begin{array}{l}6 \text { How much time do you spend talking } \\
\text { to other people or sitting on the phone? }\end{array}$ & Good variable; revealing data; suggested to improve writing. \\
\hline $\begin{array}{l}7 \text { How much time do you spend doing } \\
\text { "paperwork" or sitting office work? }\end{array}$ & $\begin{array}{l}\text { Good question; contextualized in society; useful item for detecting } \\
\text { hypokinesia; check the relevance of the term paperwork. }\end{array}$ \\
\hline $\begin{array}{l}8 \text { How much time do you spend reading } \\
\text { sitting down? }\end{array}$ & It is relevant; include other reading positions. \\
\hline $\begin{array}{l}9 \text { How much time do you spend playing a } \\
\text { musical instrument? }\end{array}$ & $\begin{array}{l}\text { Keep in mind that many people do not play a musical instrument, relevant } \\
\text { question; it depends on the instrument the energy expenditure. }\end{array}$ \\
\hline $\begin{array}{l}10 \text { How much time do you spend doing } \\
\text { crafts? }\end{array}$ & Rarely, that is why I recommend including work at home. \\
\hline $\begin{array}{l}11 \text { How much time do you spend driving } \\
\text { or riding in a car, bus or train? }\end{array}$ & $\begin{array}{l}\text { Good question; check the relevance of the word car; in Colombia trains are } \\
\text { not common; check the relevance whether it is public or private transport. }\end{array}$ \\
\hline
\end{tabular}

Source: Compiled by author

The quantitative data of the evaluation carried out by experts were taken and the Cronbach's alpha was calculated for each of the items whose values are presented in Table 3. Note how the only item with an alpha lower than 0.70 was 7 , the item with the highest Cronbach's alpha was 10, the general Cronbach's alpha of the instrument was 0.963 , this value is considered to be the optimum reliability value.

Table 3. Cronbach's Alpha results for each item

\begin{tabular}{ll}
\hline Original version item & $\begin{array}{l}\text { Cronbach } \\
\text { Alpha }\end{array}$ \\
\hline 1 How much time do you spend watching TV? & $\mathbf{0 , 8 4 7}$ \\
\hline 2 How much time do you spend sitting down? & $\mathbf{0 , 8 7 9}$ \\
\hline 3 How much time do you spend lying down? & $\mathbf{0 , 7 8 4}$ \\
\hline 4 How much time do you spend playing computer or sitting video games? & $\mathbf{0 , 7 6 7}$ \\
\hline 5 How much time do you spend listening to music sitting down? & $\mathbf{0 , 9 0 3}$ \\
\hline 6 How much time do you spend talking to other people or sitting on the phone? & $\mathbf{0 , 8 3 0}$ \\
\hline 7 How much time do you spend doing "paperwork" or sitting office work? & $\mathbf{0 , 6 7 7}$ \\
\hline 8 How much time do you spend reading sitting down? & $\mathbf{0 , 7 1 1}$ \\
\hline 9 How much time do you spend playing a musical instrument? & $\mathbf{0 , 9 0 3}$ \\
\hline 10 How much time do you spend doing crafts? & $\mathbf{0 , 9 3 4}$ \\
\hline 11 How much time do you spend driving or riding in a car, bus or train? & $\mathbf{0 , 8 1 0}$ \\
\hline
\end{tabular}

Source: Compiled by author 


\section{Final phase}

Based on last round results, a definitive version of the instrument was proposed; 3 new items suggested by the expert evaluators were included and considered pertinent by researchers, since they improve the technical quality of the instrument.
The experts suggested that these new items would complement the evaluation of sedentary behaviors, in this way, as presented in Table 4 in the column "adapted and validated version", the instrument for the Colombian context would be made up of 14 items. (Table 4)

Table 4. Results of the validated and adapted version

\begin{tabular}{|c|c|}
\hline Original version item & Item validated and adapted and Validated version \\
\hline $\begin{array}{l}1 \text { How much time do you Employee watching } \\
\text { TV? }\end{array}$ & 1 How much time do you spend watching TV? \\
\hline 2 How much time do you spend sitting down? & $\begin{array}{l}2 \text { How much time do you spend eating, without any } \\
\text { movement? }\end{array}$ \\
\hline 3 How much time do you spend lying down? & $\begin{array}{l}3 \text { How much time do you spend resting in a sitting, } \\
\text { lying or reclining position? }\end{array}$ \\
\hline $\begin{array}{l}4 \text { How much time do you spend playing computer } \\
\text { or sitting video games? }\end{array}$ & $\begin{array}{l}4 \text { How much time do you spend on any technological } \\
\text { equipment in a sitting, lying or reclining position? }\end{array}$ \\
\hline $\begin{array}{l}5 \text { How much time do you spend listening to music } \\
\text { sitting down? }\end{array}$ & $\begin{array}{l}5 \text { How much time do you spend listening to music } \\
\text { sitting down? }\end{array}$ \\
\hline $\begin{array}{l}6 \text { How much time do you spend talking to other } \\
\text { people or sitting on the phone? }\end{array}$ & $\begin{array}{l}6 \text { How much time do you spend sitting, lying or } \\
\text { leaning over talking to other people, in person or on } \\
\text { the phone? }\end{array}$ \\
\hline $\begin{array}{l}7 \text { How much time do you spend doing } \\
\text { "paperwork" or sitting office work? }\end{array}$ & 7 How much time do you spend doing office work? \\
\hline $\begin{array}{l}8 \text { How much time do you spend reading sitting } \\
\text { down? }\end{array}$ & $\begin{array}{l}8 \text { How much time do you spend reading in a sitting, } \\
\text { lying or reclining position? }\end{array}$ \\
\hline $\begin{array}{l}9 \text { How much time do you spend playing a musical } \\
\text { instrument? }\end{array}$ & $\begin{array}{l}9 \text { How much time do you spend playing a musical } \\
\text { instrument? }\end{array}$ \\
\hline 10 How much time do you spend doing crafts? & $\begin{array}{l}10 \text { How much time do you spend doing crafts or other } \\
\text { work at home? }\end{array}$ \\
\hline \multirow[t]{4}{*}{$\begin{array}{l}11 \text { How much time do you spend driving or riding } \\
\text { in a car, bus or train? }\end{array}$} & $\begin{array}{l}\mathbf{1 1} \text { How much time do you spend traveling by car and/ } \\
\text { or public transportation? }\end{array}$ \\
\hline & 12 How many hours on average do you sleep daily? \\
\hline & $\begin{array}{l}13 \text { How many hours do you spend at work sitting } \\
\text { down? }\end{array}$ \\
\hline & $\mathbf{1 4}$ How many hours do you walk a day? \\
\hline
\end{tabular}

Source: Compiled by author 


\section{Discussion}

The process of content validation of an instrument by the Delphi technique becomes relevant to the extent that it allows, from the experts' judgment, adapting it to the specific context of work. Not performing this process can generate risks such as those described by Juárez and Tobón (26), for instance, the inclusion of items that do not present relevance or importance for the construct to be measured stands out because at the end of the study erroneous conclusions may be drawn due to lack of understanding of what is required. Its use for validation processes has increased significantly and it is currently reaching a relevant level of appropriation in different areas of knowledge, as described by Cabero and Infante, 2014 (27).

In the validation of an instrument by the Delphi technique, it is necessary to carry out a process of selection of the experts in a rigorous and systematic way according to the silver objectives for the research, as described by Juarez and Tobon (26). This selection is configured at the critical stage to obtain useful results from relevant and comprehensive evaluations.

As presented in the results of this research, almost $50 \%$ of the participating experts had doctoral training and more than 5 years of experience, which supports the quality and relevance of the selection process by researchers. As described by López (28), these two criteria allow estimating the level of expert knowledge of the guest together with the assessment of other indirect indicators, among them, publications on the subject, citations received and professional trajectory. Other authors highlight that in the validation processes of content the selected experts are related to the quality of the result obtained (29).

The research carried out by García, Antúnez and Ibáñez (30) shows the importance of qualitative assessment using the Delphi technique given that it is possible to identify needs for change or improvement in aspects related to semantics and writing. This was evident in the results of the present study, where the lowest ratings of some of the items could be attributed to the poor use of terms in the Colombian context.

Qualitative results require an instrument with an optimal degree of reliability, which is reflected in the value of Cronbach alpha of 0.963 , results similar to those found by Garcia et al, who obtained an overall reliability index of 0.974 in the year 2019 (31).

Once the exploratory phase is finished, the final version of the instrument must respond to its specific purposes, to the subject population with whom it will be implemented, to the demands of the research team and to the research itself. The concordance of the evaluations carried out and the analysis of the qualitative and quantitative team will finally determine the validity and reliability of the instrument for its use (32). In this regard, the results of this phase in this research allowed structuring the definitive version of the SBQ instrument adapted and validated in its content to the Colombian context.

The results of this research in which the use of the Delphi technique allowed a content validation process for an instrument that provides elements for the area of Health and Sport confirm the findings of García et al (33), López \& Calvo (34) and Torres et al (35). These authors claim that this method is a useful alternative to validate instruments in the area of Health Sciences and Sports.

From the content validation, they reformulated and included 3 new items to the instrument, which improve the technical quality of the instrument in its content and guarantee a better adaptation to the Colombian context $(36,37)$.

The authors acknowledge as a possible limitation of this study the non-participation of the 26 experts contacted initially, in this regard the literature 
confirms that it is a common situation (38). In the academy, an instrument adapted and validated in its content makes it possible to carry out research that combines different ways of assessing and reconfirming the levels of sedentary lifestyle in the population.

\section{Conclusions}

The content validation process showed that the Sedentary Behavior Questionnaire is a valid instrument that is easy to apply and fill out. It allows a first approach to the sedentary behaviors of the subjects and can be complemented with physical tests to define the level of sedentary lifestyle. It also allows the structuring of promotion and prevention programs, by applying an instrument adapted and validated to the Colombian context, its results enable decision makers in different contexts to formulate public policies aimed at promoting physical activity. 


\section{Bibliographical references}

1. Fernández D, Moral I, Puig M, Vilella T, Brotons C. Actividad física y prevención cardiovascular. APSalut. 2019;7(3):3-7.

2. Bazan N, Laiño F, Valenti C, Echandía N, Rizzo L, Fratin C. Actividad física y sedentarismo en profesionales de la salud. Rev Iberoam Ciencias la Act Física y el Deport. 2019;8(2):1-12. https:// doi.org/10.24310/riccafd.2019.v8i2.6458

3. Cristi-Montero C, Celis-Morales C, Ramírez-Campillo R, Aguilar-Farías N, Álvarez C, RodríguezRodríguez F. Sedentary behaviour and physical inactivity is not the same!: An update of concepts oriented towards the prescription of physical exercise for health. Rev Med Chil [Internet]. 2015 Aug 1 [cited 2020 Nov 2];143(8):1089-90. Available from: https://pubmed.ncbi.nlm.nih.gov/26436943/

4. OMS | Inactividad física: un problema de salud pública mundial. WHO. World Health Organization; [Internet] 2018. [cited 2020 Nov 2]. Available from: https:/www.who.int/dietphysicalactivity/ factsheet_inactivity/es/

5. Arocha Rodulfo JI. Sedentary lifestyle a disease from XXI century. Clin e Investig en Arterioscler. 2019 Sep 1;31(5):233-40.

6. Minsalud. Análisis de Situación de Salud (ASIS) Colombia, 2018 [Internet]. 2019 [cited 2020 Feb 2]. p. 273. Available from: https://www.minsalud.gov.co/sites/rid/Lists/BibliotecaDigital/RIDE/VS/ ED/PSP/asis-colombia-2018.pdf

7. Murillo AL, Rangel LG, Gamboa EM, Sánchez JC. Estudio correlacional sobre la actividad física y conducta sedentaria en senderistas de Bucaramanga, Colombia. Rev Cuba Investig Biomédicas [Internet]. 2020 [cited 2020 Nov 2];39(1):e154. Available from: http://www.revibiomedica.sld.cu/ index.php/ibi/article/view/154

8. Rosenberg D, Norman G, Wagner N, Patrick K, Calfas K, Sallis J. Reliability and validity of the sedentary behavior questionnaire (SBQ) for adults. J Phys Act Heal. 2010 Nov;7(6):697-705.

9. Robinson T. Reducing children's television viewing to prevent obesity: A randomized controlled trial. J Am Med Assoc. 1999 Oct;282(16):1561-7.

10. Rivière F, Aubert S, Omorou A, Ainsworth B, Vuillemin A. Taxonomy-based content analysis of sedentary behavior questionnaires: A systematic review. PLoS ONE. Public Library of Science; 2018; 13: 1-25https://doi.org/10.1371/journal.pone.0193812

11. Chu A, Ng S, Koh D, Müller F. Domain-specific adult sedentary behaviour questionnaire (ASBQ) and the GPAQ single-item question: A reliability and validity study in an Asian population. Int $\mathrm{J}$ Environ Res Public Health. 2018;15(4):1-13. https://doi.org/10.3390/ijerph15040739

12. Zengin A. Cultural adaptation of sedentary behavior questionnaire and reliability, validity research of Turkish version. Natl Libr Med. 2018;

13. Munguía D, Segura V, Camiletti D, Álvarez I, Estévez F, Romero A, et al. Spanish adaptation and psychometric properties of the sedentary behaviour questionnaire for fibromyalgia patients: The alandalus study. Clin Exp Rheumatol. 2013;31(Suppl.79):22-33.

14. González López A, Céspedes del Fierro S, Montes Rodríguez F. Personal Branding: una tendencia del marketing holístico como proceso formativo [Internet]. 2017. 206 p. Available from: http:// www.cuadernosartesanos.org/2017/cac135.pdf

15. Niño Bautista L, Hakspiel Plata MC, Mantilla Hernandez LC, Cardenas Herrera MS, Guerrero Parra NC. Adaptación y validación de instrumento para evaluar habilidades psicosociales y hábitos saludables en escolares. Univ y Salud. 2017;19(3):366-77. https://doi.org/10.22267/rus.171903.99 
16. Urzúa A, Marmolejo A, Barr C. Validación de una escala para evaluar factores vinculados a la adherencia terapéutica en pacientes oncológicos. Univ Psychol. 2012;11(2):587-98. https://doi. org/10.11144/Javeriana.upsy11-2.veef

17. Norman G, Schmid B, Sallis J, Calfas K, Patrick K. Psychosocial and environmental correlates of adolescent sedentary behaviors. Pediatrics. 2005 Oct;116(4):908-16. https://doi.org/10.1542/ peds.2004-1814

18. Blasco J, López A, Mengual S. Validación mediante el método Delphi de un cuestionario para conocer las experiencias e interés hacia las actividades acuáticas con especial atención al Winsurf. Ágora para la Educ física y el Deport. 2010; 12(1):75-94

19. Bravo M, Arrieta J. El método Delphi. Su implementación en una estrategia didáctica para la enseñanza de las demostraciones geométricas. Rev Iberoam Educ. 2005;36(7):1-10.

20. Betancurth D, Vélez C, Jurado L. Validation and adaptation of the Fantastico questionnaire by Delphi technique. Salud Uninorte. 2015;31(2):214-27. http://dx.doi.org/10.14482/sun.31.2.5583

21. Lugo L, García H, Gómez C. Confiabilidad del cuestionario de calidad de vida en salud SF-36 en Medellín, Colombia. Fac Nac Salud Pública El Escen para la salud pública desde la Cienc. 2006;24(2):7.

22. González R, Llapur R, Díaz M, Illa M, Yee E, Pérez D. Estilos de vida, hipertensión arterial y obesidad en adolescentes. Rev Cubana Pediatr. 2015;87(3):273-84.

23. Torres C, Illera D, Acevedo D, Cadena M, Meneses L, Ordoñez P, et al. Riesgo cardiovascular en una población adolescente de Timbío, Colombia. Rev la Univ Ind Santander Salud. 2018 Mar;50(1):5966. http://dx.doi.org/10.18273/revsal.v50n1-2018006.

24. Tremblay M, Aubert S, Barnes JD, Saunders T, Carson V, Latimer A, et al. Sedentary Behavior Research Network (SBRN) - Terminology Consensus Project process and outcome. Int J Behav Nutr Phys Act. 2017;14(1). https://doi.org/10.1186/s12966-017-0525-8

25. Landis J, Koch G. The measurement of observer agreement for categorical data. Biometrics. 1977 Mar;33(1):159.

26. Juárez LG, Tobón S. Análisis de los elementos implícitos en la validación de contenido de un instrumento de investigación. Rev Espac. 2018;39(53):23-30.

27. Cabero J, Infante A. Empleo del método Delphi y su empleo en la investigación en comunicación y educación. Edutec. 2014;48:e272.

28. López-Gómez E. El método Delphi en la investigación actual en educación: Una revisión teórica y metodológica. Educ XX1. 2018;21(1):17-40.

29. Pedrosa I, Suárez J, García E. Evidencias sobre la validez de contenido: avances teóricos y métodos para su estimación. Acción Psicológica [Internet]. 2014;10(2):3-20. Available from: http://dx.doi. org/10.5944/ap.10.2.11820

30. García-Martín A, Antúnez A, Ibáñez SJ. Análisis del proceso formativo en jugadores expertos: validación de instrumento. Rev Int Med y Ciencias la Act Fis y del Deport. 2016;16(61):157-82. https://doi.org/10.15366/rimcafd2016.61.012

31. Andrés García I, Muñoz Moreno MF, Ruíz López Del Prado G, Gil Sáez B, Andrés Puertas M, Almaraz Gómez A. Validation of a questionnaire on attitudes and practice of physical activity and other healthy habits through the Delphi method. Rev Esp Salud Publica [Internet]. 2019 Sep 16 [cited 2020 Feb 2];93. Available from: http://www.ncbi.nlm.nih.gov/pubmed/31523053

32. Soriano AM. Diseño y validación de instrumentos de medición. Diá-logos. 2014;14:19-40. https:// doi.org/10.5377/dialogos.v0i14.2202 
33. García I, Moreno MF, López Del Prado G, Sáez B, Puertas M, Gómez A. Validación de un cuestionario sobre actitudes y práctica de actividad física y otros hábitos saludables mediante el método Delphi. Rev Esp Salud Publica. 2019;93:1-12.

34. López Vidal F, Calvo LLuch Á. Diseño y validación mediante Método Delphi de un cuestionario para conocer las características de la actividad física en personas mayores que viven en residencias. Retos. 2019;36:515-20. https://doi.org/10.47197/retos.v36i36.69773

35. Torres G, De Rosende Celeiro I, Reigosa DR, Valeiro MAG, Ivette A, Alvarez Á. Diseño y validación de un cuestionario para conocer las decisiones de programación de los contenidos del entrenamiento en balonmano (PCE-BM). Retos. 2019;36(2):427-34. https://doi.org/10.47197/retos.v36i36.68252

36. Arias Masa J, Contreras Vas JÁ, Martín Espada RM, Melo Andrade M. Validación de un cuestionario de satisfacción para la introducción de la gamificación móvil en la educación superior. RISTI Rev Ibérica Sist e Tecnol Informação, ISSN-e 1696-9895, № 23, 2017, págs 33-45 [Internet]. 2017 [cited 2020 Nov 2];(23):33-45. Available from: https://dialnet.unirioja.es/servlet/articulo?codigo=667342 $6 \&$ info $=$ resumen\&idioma $=\mathrm{ENG}$

37. Martin-Romera A, Molina Ruiz E. Valor del conocimiento pedagógico para la docencia en Educación Secundaria: diseño y validación de un cuestionario. Estud pedagógicos [Internet]. 2017;43(2):195220. Available from: https://dx.doi.org/10.4067/S0718-07052017000200011

38. Salvador P, Mariz C, Vítor A, Ferreira J, Fernandes M, Martins J. Validation of virtual learning object to support the teaching of nursing care systematization. Rev Bras Enferm. 2018;71(1):11-9. https://doi.org/10.1590/0034-7167-2016-0537 